Original Research Paper

\title{
Great Game in Central Asia: Causes and Consequences
}

\author{
Ali Muhammad Bhat \\ Department of Islamic Studies, Islamic University of Science and Technology, \\ Awantipora 192122 Pulwama Jammu and Kashmir India
}

\author{
Article history \\ Received: 06-06-2020 \\ Revised: 03-08-2020 \\ Accepted: 22-08-2020 \\ Email: alimohd1265@gmail.com
}

\section{Introduction}

The theory of the great game has led numerous evaluations which involved five republics of central Asia as chessboard where international players are trying to win according to their interests. This game started earlier by British cum Russian cold war in the region for dominance but with course of time other new players like China and US led Europe united to counter the Russian and the rising influence of China (Alder, 1879). The ground was provided by local rulers who always for their own comforts tied themselves with the world powers and never tried to emerge as power bags themselves. Their resources were and are utilized by world powers due to ruling dynasties or parties incompetence's. In the 19th century, local Afghan rulers, their palace rivalries and dynastic conflicts increasingly squeezed the Afghan empire to its present borders. Court rivalries and family disputes on power provided ample opportunity to outside enemies to understand the weaknesses of regional rulers. To take benefits of rivalries and conflicts, both the British in India and the Russians sought to bring Afghanistan under their control in order to have sway on Central Asia. This Anglo-Russian rivalry (called the Great Game) (Boulger,
1879) earlier resulted in two wars, the First AngloAfghan War (1838-1842) and the Second Anglo-Afghan War (1878-1880) in which British face stiff resistance and crushing defeats. But still the result was, the British secured control of Afghanistan's foreign relations.

Historically speaking it does not happened all of a sudden but due to course of new situation emerged from weak and quarrelling rulers of Durrani dynasty when they face Russia from north and on eastern border the British India. These rulers fought for personal benefits and lost much of their strength in these wars. This provided chance to external aggressors to develop their influence. The major blow for Afghanistan's Durrani dynasty in the nineteenth century, was to counter the rising power of the Russia having intention to bring under control whole region of central Asia for a lunge against Britain's Indian empire. Whole Central Asia except Afghanistan was directly under the control by USSR. In this way they put halt on the British to remain within its Indian boundaries. Due to this cold war design, British failed in its attempts to control central Asia and moved towards new methods offered cash subsidies, manipulated the tribal chiefs and managed to turn Afghanistan into a client state. On the other side Russia 
was playing its mighty cards and build pressure on the Afghan governments to accept its influence sometimes directly and sometimes indirectly. This 'Great Game' between two rival powers, Russia and Britain, divide the Afghan society through covert war of acumens and corruption and sporadic military pressure as both powers kept each other at a distance by maintaining Afghanistan as a nerve for buffer state between themselves (Kaye, 1851).

The internal rivalry between ruling Durrani dynasty was feuds amongst the ruling Duran's which were motorized by British intelligence officers in order to keep Afghan kings weak and dependent on British munificence. This wrecked condition resulted, nonPashtun implemented the autonomy from central rheostat of Kabul. Due to heavy military pressure by British on the North West India and the conquest of area divided the NWFP in two regions, one controlled by British India and another by Kabul government. This gave rise to a new border line known as Durand line, a formal demarcation line by British in 1893. A drastic change occurred when British supported Amir Abdul Rahman's ('Iron Amir' 1880-1901 as he was called), claim to the throne to centralize and strengthen the Afghan state. While using effectively the British subsidies and arms supplies, the Amir downcast rebellious Pashtun tribes and in north ended the autonomy of the Hazaras and Uzbeks. Abdul Rahman with the help of British crush massive array of revolts and created Afghanistan's first brutal secret police force, a antecedent to the communist Khad in the 1980s. He vehemently supported to Islamists to have grip on the power particularly Pashtun Ulama and emphasised on the introduction of divine rule and rejected traditional pattern of election through the Loya Jirga.

The rule of the Durrani dynasty came to end when Daud, forced Zaheer Shah to exile to Rome and declared Afghanistan a Republic. He did this all with help of communist leftist officers in the army and Babrak Karmal a small, urban-based Parcham party to crush an embryonic Islamic fundamentalist movement (Saikal et al., 2004). The Russian influence is observed everywhere in Afghanistan from administration to education as well as land reform and women empowerment. Due to hard pressure by communist rulers, the Islamist fled to Pakistan and came direct under the influence of Pakistan government. This gave rise to new disputes between Pakistan and Afghanistan as Afghan government claimed KPK as its integral part (Rashid, 1998). To achieve this goal Russia along with India helped the some secret armed groups in Pakistan to liberate the KPK. Pakistan on the other side with the help of new player in this game USA developed new strategy and used Islamic card against communist Russia and Afghan government. All these favours either to
Afghan government or to Islamists or communists gave rise to cold war which resulted in disintegration of USSR now termed as great game. In order to achieve the benefits of Central Asian resources and tactics was used which is later coined known as Great Game (Davis, 1920).

The classic Great Game passé is commonly considered as just about from the Russo-Persian Treaty of 1813 to the Anglo-Russian Convention of 1907. The term "The Great Game" is usually attributed to Arthur Connolly, an intelligence officer of the British East India Company. Actually the Great Game is a geopolitical rivalry as the word indicates, it helps to understand the relationship between geopolitical locations its effects on the behaviour of a region with other countries and directions it chooses to play its role in the world affairs. Many reasons are behind the great game in central Asia but the most effective is economy and geo strategic location though technology also played an important role in it. In such circumstances, these factors witnessed the new trends and patterns of geopolitical relations after the collapse of the bipolar system. The uni-polarity of the world gave US an edge to exert much pressure to be available in every part of the central Asia, after the disintegration of the Soviet Union. Sho'laye Jawed attacked both the Soviet Union and the US as revisionist and imperialist powers respectively (Saikal et al., 2004).

Observing the phenomenon of history, the great game was started by Russia when employed the local rulers against each other. Russia faced tough resistance particularly when the Khans of Bokhara when they defeated the Russian Tsar army two times around 1717 and 1839-40. The great game term coined by British political philosophers, have roots deep in Russian colonial design (Roudik, 2007). A good number of works focus on the dominance of the Russian great game plan to keep the Western and other European powers at bay. Seymour Becker's Russia's Protectorates in central Asia: Bukhara and Khiva 1865-1924 and Alex Marshall: The Russian General Staff and Asia, 18001917 etc. Central Asia according to Mackinder's geopolitical theory is the Core of the world politics. It has been the chessboard of imperial rivalry existed between British and Russian empires caused by their expansionist polices of both the powers. So there had been a competition between British and Russia to have influence over Central Asia owing to its location at crossroads of different civilizations and old silk route. The significance of this imperial rivalry was attributed by Mackinder's geopolitical analysis and named it as heartland. So whoso ever wanted to be an influential power player in terms of political dominance with economic fruition had to turn towards Mackinder conception of Heartland (Fatima, 2012)?

A great upheaval was observed in central Asia between the military powers of Europe are Asian 
contenders and tried their best to dominate on the Eurasia. Starting the mayhem from British, who were in hurry to develop sphere of influence as possible as it can to remain as dominant power for centuries? A strong contending power in the shape of France and then Russia to have their influence on the Asia's political decay. Though France started its influencing strategy but failed to achieve its objectives in Asia particularly in Central Asia. Russian turned as strong power to have hold on the caravan routes of the ancient conquerors, threatening to establish a new world monarchy. Spotting this whole mechanism of power struggle England, being a strong colonial power came with its might to keep Russia and its growing influence away from the South Asia. According to Fromkin D, "In the last quarter of the nineteenth century, it was comparatively consensual, in Europe, that the next major war - the inevitable war would be the final confrontation between Britain and Russia (Fromkin, 1980)."

Historically speaking the rehearsal of the great game stared when a group of British Army Officers stared their assignment via Nushki Baluchistan to explore central Asia for strategic politico-economic purposes. The young British Officers, Captain Charles Christie and Lieutenant Henry Pottinger, both of the $5^{\text {th }}$ Bombay Native infantry were affianced on an intelligence or on a secret reconnaissance through wild and lawless Afghanistan (Hopkrik, 1990). Earlier no one dared to explore the region due to its tough terrains and lawlessness. Earlier it was General Malcolm along with some low rank officials of British army to headway towards Persia to train the Persian military with a purpose to understand the region (Ibid, 73-74).

Intelligence mission of these Bombay Officials (Christie and Pollinger) was hidden but failed to achieve objectives when detected and forced to abandon their journey, otherwise face harsh bastinado or even death. Both the groups of military secret officials reached to afghan-china border and henry Pottinger return to Bombay from his mission but the Charles Christie managed to reached Herat a gate to central Asia and successfully completed his secret military adventure and recce and later en-route to Mashhad for pilgrimage (Ibid, 79-80).

The purged phenomenon of communication, encounter and discrepancy of local and worldwide interests, resulted in what Arthur Connolly has called "Great Game" of quest for power and influence in the region (Lansford, 2002). Two historical landmarks have changed discourse and gamut of great game, that are "The Russo-Persian Treaty of 1813 and the AngloRussian Convention of 1907" though in spite of having been branded by less passionate engagement after the Bolshevik Revolution in 1917 (Kelly, 2000).

Granting Arthur Connolly the title of being father of the term "Great Game", but actually it was the writer
Rudyard K, who in his novel Kim (1901), made known this concept to the hoi polloi. The Great Game being a conspiracy fought on the basis of cold war design by two imperial powers, for political dominance, control and security of the territories located between the Russian and British Empires. Indeed, the Great Game was fought behind the curtain and these imperial powers never came face to face to each other instead fought in the heartland of central Asia - an area yet unknown to both rivals. On the other hand, the 'dreaded' and anxiety inroad, invasions are always put on table by both powers on priority basis, but that never came to materialise. So, it is necessary to quote David Fromkin, for whom "the nature of the dispute has been described in many different ways" (Fromkin, 1980) According to him, the Great Game in central Asia have three major periods which in which Russia manipulated everything to achieve dominance in the region. All the three phases are important so as to under the great game in central Asia because others too used the almost same but differently tactics to achieve their objectives. Firstly Russia in late $18^{\text {th }}$ and early $19^{\text {th }}$ century, initiated its expansionist agenda to Caucasus and other parts of the central Asia with the aim to force British East Indian company to remain away from central Asia and give-up its colonial/imperial agenda. Second period stated when Russian government and its intelligence offices used the secret goals in order to influence but public psyche and manipulate as well as dominate on their interests for achieve their goal. This period lost for 10 years from 1907 to 1917. Russian resorted to every tactics and methodology for achieving their objectives. The final or third phase of the Great Game is much interesting, strong and more colonial in design, after the Russian Revolution of 1917. Under the leadership of Lenin Bolsheviks, set forth to "set free, the whole of Asia from British imperialist domination" through armed revolts. One thing strange happened in this period, Bolshevik's got stronger and consolidated their strength over the former tsarist territories (Hopkirk, 2002).

In fact, they are expanding empires one forceful intruding through India to Afghanistan, while as other tightening rheostat over central Asia for ever. The axis of sombreness or focal point for both expanding empires was Afghanistan. The British were afraid of aggressive communist Russian lunge on Herat from the Turkmen expanse and could daunt British Baluchistan, while Moscow strategies could turn Kabul's rulers against the British. The Russians were scared that the British would undercut them in Central Asia by assisting Muslim tribal insurgencies and the rulers of Bukhara and Kokand. Mackinder's Pivot concept was introduced while the Great Game was still going on. Mackinder indeed realized the importance of territorial control over vast, continental expanses in the centre of the Eurasian 
landmass. It was a sporadically populated and developed area, but extremely difficult to reach from the sea, because of its remoteness and inaccessibility, especially considering the level of technological development a century ago. Observing the whole design of great game Mackinder changed the boundaries by applying the strategic framework of the era and came with his formula in 1904, 1919 and 1943. His main design always include in the great game countries like countries of Afghanistan, Kazakhstan, Kyrgyzstan, Tajikistan, Turkmenistan and Uzbekistan), western Siberia and the northern portions of Iran and Pakistan. Iran and Pakistan being coastal countries having strong access to hot waters of the region will serve as network to bring resources of Central Asia to all other parts of the world. Because whole central Asian region is naturally a "the greatest natural castle on earth (Seiple, 2004)".

The British geographer considered central Asia as one of the pillars of geopolitics and geographical pivot of history has put fuel in to fire, while defining the central Asia as the Heartland. He conceived the concept in 1904 which has fundamental implications to understand the regions greatness and strategic location for ever:

- "Who rules East Europe commands the Heartland

- Who rules the Heartland commands the World-island

- Who Rules the World-island commands the World"? (Mackinder, 1962)

Mackinder's analysis being a century old but is still characterised a groundwork to comprehend the geostrategic and geo-economics' value of the area. While analysing the Heartland's aphorism, control over Central Asia means sway to an utmost dominance within the global set-up (Scott and Alcenat, 2008).

After thirty three years Pottinger's nephew, Lieutenant Eldred Pottinger serving as political advisor for East India Company entered the Herat Afghanistan with the purpose of Great Game reconnaissance on August 18, 1837. He changed the complexion of his skin in order to resemble as holy Muslim man. He as British spy to make possible the surrender or subjugation of Afghanistan failed (Hopkrik, 1990). On the other side the Russian deployed its troops on the Persian Gulf to force Shah to remain away from the British game plan and to restrict their activities because British had already deployed its military officials to build its influence on the region (Ibid, 267-269).

The nineteenth and twentieth century imperial rivalry was ascribed as Great Game first by Rudyard Kipling then by Arthur Connolly, an officer from the British East India Company. According to Hopkirk" the Great Game involved three phases. The first one started with the expansion of the Russian Empire in the Caucasus and Central Asia in the late eighteenth and early nineteenth centuries, generating apprehensions in the East India Company (British), the imperial power in India. Fearing Russia's intentions, the company sent officers to explore the way, by land to the northern border of India. During the nineteenth century, the British government sought to engage more intensely in Central Asian issue, transforming the great game until then (Ibid, 201, 261).

The theory of the "New Great Game" (Kleveman, 2003) led numerous evaluations on Central Asia to consider the five republics as "flaccid dolls" of the chessboard that involves the major international players. These nations are active actors with their own political agenda, being able to determine foreign policies visible within the international system (Isaacs, 2016). The rising interests of major big powers - such as China, the United States and Europe jointly with the long-standing Russian attention toward the area are undoubted. A challenging situation emerged in late $19^{\text {th }}$ century, when British and Russia started an undeclared war of dominance, competition and influence to restrict each other or to keep each other at bay in central Asia. South Asia and Persia. Many considered it as reminiscence of outlandish vagaries and dilapidated amorousness but in reality it was a cold war as Lord Curzon wrote:

"To me, I confess they are pieces on a chessboard upon which is being played out a game for the domination of the world (Verrier, 1991)."

Situation prevailing across Eurasia presents strategic location that influence this world and its geostrategic and geo-economic significance affects the international level. The spectacular thrill of central Asia's and its indivisibility of relations from those in the neighbouring regions, psychologically involved world's superpower (US) and two great world powers (Russia and China) on rival relations. The interest of these great powers in Central Asia is defined by geostrategic and geoeconomic relations in Central Asia. They concentrate on economic values of the region since the region, together with the Caspian Sea, contains vast oil and gas fields (Kurečić, 2010). It is observed that situation between great players was war like without its announcement so as to achieve objectives having significance for economic and strategic location. As published by Mackinder in his paper The Geographical Pivot of History in 1904 in which he explained significance of the region through a map known as the map of Mackinder's pivot (Mackinder, 1904).

After the disintegration of USSR the philosophy of warfare in Afghanistan is redrafted according to new strategy. All international contenders from Alexander the great who struggled there and attempts by British, Russia and Soviet Union failed miserably and the situation forced Milton Bearden to call it "The Graveyard of 
Empires" (Wills, 2006) In this regard they change the war policies in order to have hold on the Afghan soil so as to achieve economic control of the area. For this purpose US used its air force, earlier spying by British and military offence and communist card by USSR to dominate on the region but all their efforts failed and the situation forced them to withdraw from the region without achieving anything except loss of life from both sides. According to Jim Nicole that, some policymakers and academics who were much worried about US presence in CIS. They contended that US has more hidden interests in central Asia than its counter terrorism policy in Afghanistan. It is all observed after US narrowed its relation with its allies and develop direct contacts with central Asia states. It is clear US accumulation in the region was observed to count down the Russian influence in the region. Erstwhile to 9/11, Russia tried to pre-set its strength and interests in the region so as to melt down the growth of U.S. and other influence in the region (Nicole, 2003). After 9/11, US has intentions to stay in Afghanistan in order to build its influence in the region which is perceived when Defense Secretary Donald Rumsfeld visited the region in December 2001 and April-May 2002. During his August 2002 visit, Commander Tommy Franks stated that the U.S. military presence would continue in Afghanistan and Central Asia and that military-to-military impasse with regional states will help to increase interests for regional states as well as US (Ibid, 15).

It is observed that due to this great game primarily people of Afghanistan, suffered a lot whose lives were affected and their prospects for the future destroyed (Jawad, 1992). In the great game design Afghanistan became a bone of contention and Afghan catastrophe is over shadowed by interests of all major players. All players are wrestling for maximum benefits which resulted in no solution of the problem which effects life of Afghan people. As long as foreign intervention continues both inside and outside Afghanistan, there is little chance for national reconciliation and resolution of the crisis within the country (Ibid, 38).

According to Fukuyama, "The Taciturn Conflict amongst the USSR and a USA came to end after the disintegration of Soviet Union and Warsaw pact (military alliance of six countries) ended in 1991 with the withdrawal of Russian forces. This was considered by Francis Fukuyama, as the "End of History" and declared the victory of liberal democratic forces or the US dominance over the rest of the world and considered US as the main political power in the world and end of power politics (Abilov, 2012). Since the disintegration of the USSR, Caspian region became hub of the power confrontation which gave rise to new great game in the region and has been transmogrified into the combat zone for the world's leading countries because of its vast hydrocarbon resources and it strategic location in the Eurasia. With reference to the significance of the region Dick Cheney, the former vice president of the Bush administration openly declared it during his speech to oil industries in Washington, D.C. in 1998, "I cannot think of a time when we have had region emerge as suddenly to become as strategically significant as the Caspian" (Kleveman, 2003). The Western politicians declared the Caspian Sea region as "New Middle East" for its abundant oil and natural gas resources. The Strategic and geographical position of the Caspian region and holding copious oil and gas resources pencilled the attention of the regional and global players in order to build their pillories in manipulation of Caspian hydrocarbon (Kumar, 2009).

Moreover scholars vary in their opinions about the regions geographical existence whether only five coastal states strictly make the region or other geographically linked neighbouring states too which have affinity with the region. Among those capricious opinions one is, it consists of vast territory on the borders of Europe and Asia famous with the name "Eurasian Pearl" (Zeyn et al., 2009), which includes two more regions of the former Soviet Union, Caucasus and Central Asia (Zeinolabedin et al., 2011). Other group of scholars consider the region consists of republics of central Asia, South Caucasus along with Pakistan and Afghanistan (Sasley, 2004).

After the fall of USSR the last three decades US has been one of the strong players in the new great game in the region. But the concept changed after US battle with Talban and its regional contenders discouraged US badly in the region and its long battle with Taliban forced US to share table with whom they called harbourers of terrorism. US apparently came with a thought to wipeout militancy in the region and announced to play active role in the political and economic affairs of the Caspian region. Though it was pushing itself into the region and takes all efforts to avoid rivalry and prevent formation of any political allies that challenge its position. But US failed to do so as all regional players Russia, China and Iran are coming very close to entrap US in Afghanistan. In this regard, Fouskas and Bulent defined the US policy toward the region as follows:

"Declaring itself a sole global power to prevent regional cooperation among the Caspian neighbours, US is trying to influence politico-economics of the region. The vital objective of US is to create a novel range of impact to dominate on the politico-economic sphere of the region and to develop a strong security network in order to eradicate the powers which acts as threat to its interests. For this purpose US is using its military strength to reinforce and inflate Washington's political and economic power. The anti- 
terrorist drive launched by US is actually an agenda to control resources of the Eurasia and to show its military strength against local opponents along with main regional players like China and Russia" (Fouskas and Gökay, 2005). The war against terror is a false notion propagated by US but its main objective is to tighten the nook on the region to achieve national interests. US is observing a change of Eurasia as per its national interests and devise its policies accordingly. While quoting Graham E. Fuller, James Lawson says that, "This change was and is still studied by the United States government because of national interests in the area, which specifically include natural resource extraction, stability in resource transportation and a new political and military influence resulting from a new juxtaposing with China, Russia and the Middle East (Fuller, 1992).”

In order to restrict and to create an obstacle for US dominance over the Eurasia or Caspian region, Russia from 1990 till date is always using its strategic position to maintain its influence and to keep US at bay. Russia is using pipeline politics to control the region. In 1993 and 1994, in an attempt to garner control of Ukraine's energy infrastructure and Black Sea fleet, Russia reduced gas supplies. Same tactics was applied in 2004 against Belarus, Poland and Lithuania. Russia illegally cut Kazakh oil from reaching Lithuania's Mazheikiu Nafta refinery so that it will not sell oil to non-Russian companies. Due to ongoing Russian-Ukrainian conflict, Russia in January 2006, used pipeline control in a stab to politically influence the Ukraine (Smith, 2006).

From 2005 Russia was putting its efforts to thrust the CSTO to build more sophisticated military strength. On 22-24 June 2005 the member states decided to build a network of the military options for regional peace and security. In this regard the resolution was passed to develop a combined air defence system and rapid deployment forces. To develop a strong bond for security purposes a commission for military-economic cooperation of the Organization was initiated, in order to set-out cooperation between military industries of member states (Kaczmarski, 2006).

New developments in the region to re-evaluate the security concerns in the Caspian region which was vulnerable to religious and regional card through US intervention and its allies. For this purpose Russia build an exclusive zone over CIS's in order to give impression of being a strong region contender. The Caspian region due to its attraction to religious groups from across the globe particularly serves as breeding zone to extremists from Middle East and Afghanistan (Labban, 2009).
After 9/11 the security concern increased much when US got militarily involved in this region. In this concern Russia got involved with its full strength to counter the interests of US and declared the formation of 11000 strong Rapid Reaction Force to bring them in action at the time of need if its sovereignty or sovereignty of any member organization is threatened (Smith, 2009). To counter any external threat The Shanghai Cooperation Organization re-appeared as "Shanghai Five" of China, Kazakhstan, Kyrgyzstan, Russia and Tajikistan in 1996 to solve all disputes internally and make a bond of tight security. The basic aim of the SCO is security of the region in order to fight the common enemy US and terrorism including organized crimes, extremism and illegal drug trafficking and weapons trade (Strachota, 2002).

In central Asian region new players of the region are trying to be part of the great game in the region. Among those Iran, Turkey, Saudi Arabia and Pakistan are very crucial because of their affinity to the region through religious card and closeness or border sharing with these states. The role in the region involves military, economics and political alliances are likely to determine future of Muslim Central Asia. The involvement of these regional powers also means to bring into the regional arena their respective strategic priorities, which are not of great significance but would influence the future dynamics of the great game itself. For instance, the rivalry between regional neighbours will influence some central Asian states to take side either of them. At the same time China is progressing very fast in technology and will change the cards of the great game in the region. China is proceeding through economic strength to influence the regional players and make strong economic ties with the central Asian States. In this regard they have to maintain good relation Pakistan and to have influence on Afghan groups which are very crucial for achieving economic benefits of the region. The Iranian card has importance in the region being a strong religious country though the elite class in the region is not religious but communist turned democrats. Instead the popular voice may result in the implementation of religion and they are mostly anti secular card. The central Asian states are trying to be independent from economic point of view (Olcott, 1992) and to utilize their own raw resources in their countries instead of supplying them to any outsider.

Before 1989 USSR was dominant on these states, militarily, politically and more than this ideologically and supply all raw material to Russian companies. In this great game design these state too are trying to dominate over one another and their border disputes have shattered their economy and existence. Traditionally the region is called as a shatter-belt 
between rival regional players like Russia and Persia, Russia and China, or Russia and US allies.

The greatest need for tile Muslim Central Asian states is to acquire economic self-sufficiency, which has several characteristics. The Economic Cooperation Organization (ECO) has come to be an imperative to develop the economy of the regional states. For this purpose they are trying to seek arrangements for industrialization and joint ventures with Western countries too. Earlier Central Asia was also a primary source of natural gas and its reservoirs fulfil $40 \%$ of the European and half of the Soviet Union's gas demands (Achmedow and Sljussarew, 1989). Important source for natural gas is Turkmenistan which produced 84.7 billion cubic meters of gas annually and held 70 percent of "all Central Asian reserves (Ibid, 40-43).

Now among the regional players Saudi Iranian rivalry is more important. Iran has advantage of being close to the region and sharing borders with some central Asian states. Politically Iran more liberal and cannot challenge the regional heads authority but Shia country its influence on the public sphere is very weak and is a very weak card for them. Instead Saudi Arabia being centre of Muslim faith and predominantly Sunni have great affinity with the regional people but their political structure is very conservative and conservative in nature can be an obstacle for them to influence the region. One more thing is observed both the rivals have affinity with the two rival powers USA and Russia. Iran more close to Russia while as Saudi Arabia is completely dependent on the US for technology and security.

In the region after 9/11 Russia is playing its regional card while central Asian states are trying to achieve military and economic stability. In this regard Russia is perusing to make close ties with these states. It is observed in 2005 at Shanghai Cooperation Organization (SCO) summit where the heads of state of Russia, China and most Central Asian countries called on the US and its allies to set out a schedule for their military departure from the region. The declaration of the summit forced General Richard Myers, then-chairman of the U.S. Joint Chiefs of Staff, to blame Moscow and Beijing for controlling their smaller neighbours (Tyson, 2005). While US in due course succeeded to get permission to use the military facilities and airspace for operation against Taliban in Afghanistan, but on the other side it indicated the rebirth of the "new great game" among the major external as well as internal players in the region (Wolfe, 2005).

Moreover Russia being immediate neighbour and only option for Russian state to build its ties strongly to secure its interests which it lost in Middle East due to overthrow of it allied rulers, Saddam Hussain in Iraq, Colonel Kaddafi In Libya and Now Bashir in Syria. In such circumstances Russian is trying to build its military presence in almost in all the CIS to safeguard its interests.
The chief architects of Russian foreign policy know fully, how to develop its relation for regional dominance. According to M.E. Ahrari that:
"The security of their country is inextricably linked with political developments in the near abroad. In order to emerge as a great power, Russia must concentrate on building close ties with these states. Moscow must focus on sustaining the extant economic ties with the former members of the USSR and creating new ones (of course, it is no secret that an important objective underlying these economic relationships is to sustain the dependency of these countries on Russia). Russia must insist that the former Soviet states should not only retain but strengthen security arrangements with Moscow. It is also well-known that the main purpose of these arrangements is to make sure that these states do not develop security relations with Muslim states of the Middle East, or with other states of the far abroad (Ahrari, 1994)."

\section{Conclusion}

The multifarious relations between the great and regional powers having interests in Central Asia work against tide of development instead revived great game. The war against terrorism by US and allies is observe by regional contenders as interference in the region and engaging for cold war. This resulted also to provide another major reason discontinuities in Central Asia's future development. The major historical forces that could affect U.S. interests in the region are necessarily lying there. The probability of major discontinuities resulting from these complexities, underscored by the swift collapse of the U.S.-Uzbek alliance. Same as the alliance between Russian communist aid to Afghan communist but over sighted the role of religion which had major repercussion on the people of the region. In the great game design, people in Afghanistan and in neighbouring states are worst hit and resulted in major loss of life. History is witness great game always resulted in defeat and failed to achieve its objectives what so ever of any power. But loss of property and life in the region particularly in Afghanistan and then in central Asian states and Pakistan is always ignored by the major players for economic benefits. The major powers preferred resource over life which impossibly people of the region will forget. The fact that Central Asia does represent the most important geographic region for any external power Instead to work for its development they applied cold or direct war upon the region. To achieve objectives Russia, China and the United States along with regional contenders have to 
build strong and trustworthy cooperation in the region. Although each country has extensive goals in Central Asia, the resources that are available in the region to pursue them. With the proviso that their general relations remain confrontational, no single power can achieve its objectives or take benefit from abundant natural gas and petroleum resources otherwise Central Asia region will be disrupted and may result in further loss of life. Moreover such situation would add to poverty of the region and may result in extremism which will engulf whole region even the major powers.

\section{Acknowledgment}

I acknowledge that I appreciate all those people who helped me to complete this paper on an emerging issue. I discussed things with people having sound knowledge and they encouraged and appreciated my efforts in this regrad.

\section{Ethics}

This topic is of contemporary nature and from geopolitical point of view of very high signifecance. Any ethical issue which arise after discussion I bore full responsibility of that issue and tackle academically.

\section{References}

Abilov, S. (2012). The "New Great Game" Over the Caspian Region: Russia, the USA and China in the Same Melting Pot.

Achmedow, R., \& Sljussarew, J. (1989). Energiewirtschaft. Moscow: APN Verlag.

Ahrari, M. E. (1994). Moscow and the Middle East: The Future of Strategic Relationships. Journal of South Asian and Middle Eastern Studies, 17(4).

Alder, G. J. (1879). British India's Northern Frontier (1963). David Gillard, The Struggle for Asia 1828-1914.

Boulger, D. C. (1879). England and Russia in Central Asia (Vol. 2). WH Allen.

Davis, H. W. C. (1920). History of the Blockade: Emergency Departments.

Fatima, Q. (2012). The United States Approach Towards South Asia in Changing Geo-political Environment, 1990-2000: A Case Study of India and Pakistan. Higher Education Commission.

Fouskas, V., \& Gökay, B. (2005). The new American imperialism: Bush's war on terror and blood for oil. Greenwood Publishing Group.

Fromkin, D. (1980). The great game in Asia. Foreign Affairs, 58(4), 936-951.

Fuller, G. (1992). Central Asia: The New Geopolitics. Rand Corporation.
Hopkirk, P. (2002). THE GREAT GAME REVISITED. Asian Affairs, 33(1), 58-63.

Hopkrik, P. (1990). The Great Game, on Secret Service in High Asia. John Murray (Publishers) London. 15, 38, 40, 43, 73-74, 79-80, 201, 258, 260, 261, 267-69

Isaacs, R. (2016). Geopolitics in Central Asia. CERIS Brussels.

Jawad, N. (1992). Afghanistan: A Nation of Minorities (No. 92). London: Minority Rights Group.

Kaczmarski, M. (2006). Russia creates a new security system to replace the CIS. EURASIA. org, 10.

Kaye, J. W. (1851). History of the War in Afghanistan (Vol. 2). R. Bentley.

Kelly, D. (2000). End of the great game: British intervention in Russia's Southern Borderlands and the Soviet response. The Journal of Slavic Military Studies, 13(4), 84-100.

Kleveman, L. (2003). The new great game: blood and oil in Central Asia. Grove Press.

Kumar, P. (2009). The unrealized dream of Caspian Oil. International Politics, 2(4), 9.

Kurečić, P. (2010). The new great game: rivalry of geostrategies and geoeconomies in Central Asia. Hrvatski geografski glasnik, 72(1), 21-46.

Labban, M. (2009). The struggle for the heartland: Hybrid geopolitics in the Transcaspian. Geopolitics, 14(1), 1-25.

Lansford, T. (2002). The Great Game Renewed? USRussian rivalry in the Arms Trade of South Asia. Security Dialogue, 33(2), 127-140.

Mackinder, H. (1962). The Geographical Pivot of History in Democratic Ideals and Reality.

Mackinder, H. J. (1904). The geographical pivot of history. Royal Geographical Society.

Nicole, J. (2003). Central Asia's New States and Political Developments and implication for US Interests. Congress Research Services and The Library services.

Olcott, M. B. (1992). Central Asia's post-empire politics. Orbis, 36, 253-268.

Rashid, A. (1998). Taliban, Islam oil and New Great Game in Central Asia. I.B. Tauris, Publishers, London.

Roudik, P. (2007). The history of the Central Asian republics (Vol. 175). London: Greenwood Press.

Saikal, A., Farhadi, R., \& Nourzhanov, K. (2004). Modern Afghanistan: A History of Struggle and Survival. London: I.B.Tauris.

Sasley, B. (2004). The Intersection of Geography and Resources: Geopolitics in the Caspian Sea Basin. Geopolitics: Global Problems and Regional Concerns, 191-207.

Scott, M., \& Alcenat, W. (2008). Revisiting the Pivot: The influence of heartland theory in great power politics. Comparative Strategy, 22, 109-129. 
Seiple, C. (2004). Heartland Geopolitics and the Case of Uzbekistan. Foreign Policy Research Institute.

Smith, J. M. (2009). The great game, round three. The Journal of International Security Affairs, 17.

Smith, K. (2006). Defuse Russia's energy weapon'. International Herald Tribune, 17.

Strachota, K. (2002). Russian Policy in the Caucasus and Central Asia. Toward an Understanding of Russia; New European Perspectives, 128.

Verrier, A. (1991). Francis Young husband and the Great Game. Jonathan Cape.
Tyson, A. S. (2005). Russia and China Bullying Central Asia, US Says. Washington Post, 15.

Wills, C. D. (2006). Airpower, Afghanistan and the Future of warfare: An Alternative View. Air University press, Alabama.

Wolfe, A. (2005). The 'Great Game' Heats Up in Central Asia. Power and Interest News Report, 3.

Zeinolabedin, Y., Yahyapoor, M. S., \& Shirzad, Z. (2011). The Geopolitics of Energy in the Caspian Basin.

Zeyn, A. Y., Yahyapour, M. S., \& Shirzad, Z. (2009). Geopolitics and environmental issues in the Caspian Sea. 